UDC 541.13

\title{
SOME FEATURES OF ELECTROCHEMICALLY DEPOSITED CdS NANOWIRES
}

\author{
A.Sh. Aliyev ${ }^{1}$, V.A. Majidzade ${ }^{1}$, N.Sh. Soltanova ${ }^{1}$, D.B. Tagiyev ${ }^{1}$, V.N. Fateev ${ }^{2}$ \\ ${ }^{1}$ Institute of Catalysis and Inorganic Chemistry \\ National Academy of Sciences of Azerbaijan \\ 113, H.Cavid ave., AZ 1143, Baku; e-mail: chim.prob.tur@rambler.ru \\ ${ }^{2}$ «Kurchatov Institute» Russian National Research Center
}

Received 12.03.2018

\begin{abstract}
The crystallographic structure and elemental composition of cadmium sulfide (CdS) nanowires (NW) with diameters ranging between 30-40 $\mathrm{nm}$ were prepared by means of electrodepositing CdS from non-aqueous solution containing cadmium chloride ( $\left.0.2 \mathrm{M} \mathrm{CdCl}_{2}\right)$, sulfur(0.02 $\left.\mathrm{M} \mathrm{S}_{8}\right)$, and ammonium chloride $\left(0.1 \mathrm{M} \mathrm{NH}_{4} \mathrm{Cl}\right)$ dissolved in ethylene glycol at $\mathrm{T}=120-130^{\circ} \mathrm{C}$ and deposited at $90-100^{\circ} \mathrm{C}$ into pores of anodic aluminum oxide. CdS-deposited nanowires were examined by means of energy dispersion $X$-ray spectrometry (EDX), X-ray diffractometry (XRD), Raman scattering and photoluminescence (PL)spectra. It was determined that the selected electrolyte composition and electro-deposition conditions make it possible to form the CdS nanowire with a predominantly hexagonal modification while the stoichiometric composition is suitable for the use in solar energy converters.
\end{abstract}

Keywords: nanowire, cadmium sulfide, electrochemical deposition, non-aqueous solution, ethylene glycol, XRD, EDX, Raman scattering, photoluminescence spectra

\section{INTRODUCTION}

Currently, CdS is widely used in solar photovoltaic (PV) converters as a transparent conductive barrier layer. Cadmium sulfide (CdS) is a commonly used n-type semiconductor as a window layer for hetero-junction solar cell application. By selecting proper p-type semiconductor as an absorber layer, researchers have developed many kinds of hetero-junction solar cells, among which $\mathrm{CdS} / \mathrm{Cu}_{2} \mathrm{~S}, \mathrm{CdS} / \mathrm{CdTe}$, and $\mathrm{CdS} / \mathrm{CdS} / \mathrm{CuInGaSe}{ }_{2}$ combinations are the most promising solar cells [1].

The deposition of CdS films and nanowires (NW) was explored using different techniques: magnetron sputtering [2,3], sol-gel process [4], chemical bath deposition and electrodeposition [5-7]. The electrochemical deposition is widely used in the manufacture of solar cells due to low costs, relative simplicity in the production of NW and possibility to obtain high-quality polycrystalline NW of stoichiometric composition on substrates with a large surface area [4-6]. This feature of electrochemical deposition is especially important for mass production of solar cells. In addition, by controlling the potential of the working electrode in this deposition technology, it becomes possible to produce semiconductor layers with predetermined composition and properties. The growth of NW in the course of electrochemical deposition occurs under equilibrium conditions, which makes it possible to reduce the concentration of defects. This method is effective in obtaining $\mathrm{NW}$ as compared with other deposition methods. Despite the availability of a great number of publications devoted to the synthesis of CdS NW, the structure and phase composition of the synthesized NW remains insufficiently studied.

We have chosen method from nonaqueous solution to deposition route to deposit CdS thin film over glass sample because it offers deposition over a large area. It also 
provides other advantages, such as low temperature operation and economic feasibility. Many authors succeeded in gaining the highest efficiency due to this method and growing transparent optic window for CdTe and CIGS solar cells [4-6]. In this work, we report CdSNW grown in pores of AAO templates at $90 \pm 2^{\circ} \mathrm{C}$ by electrochemical deposition from containing $0.2 \mathrm{M} \mathrm{CdCl}_{2}, 0.02 \mathrm{M} \mathrm{S}_{8}, 0.1 \mathrm{M} \mathrm{NH}_{4} \mathrm{Cl}$ dissolved in ethylene glycol (non-aqueous solvent) and its characterization by various techniques like XRD, SEM, Raman spectroscopy and PL spectroscopy.

\section{EXPERIMENTAL DETAILS}

The indium-tin oxide (ITO) and aluminum layers were deposited on glass substrates by reactive high-frequency magnetron sputtering method onZ-550 Leybold-Heraeus unit in a mixture of argon and oxygen inside the chamber $[7,8]$. Then nanoporous anodic aluminum oxide (AAO) templates were prepared through the two - step anodisation process in a 0.1 Moxalic acid solution, as described in detail in [7-9]. The electrodeposition of CdS nanowire into the AAO pores was carried out by potentiostatic method in a homemade two-electrode electrochemical cell equipped with a temperature sensor, an electric heater and an electric mixer from the non-aqueous solution containing $0.2 \mathrm{M} \mathrm{CdCl}_{2}, 0.02 \mathrm{M} \mathrm{S}_{8}, 0.1 \mathrm{M}$ $\mathrm{NH}_{4} \mathrm{Cl}$ dissolved in ethylene glycol at $\mathrm{T}=130^{\circ} \mathrm{C}$. Electrochemical deposition was carried out in potentiostatic conditions at $90 \pm 2^{\circ}$ C.The electrolyte was constantly mixed, the deposition time was 10-100 sec, and the current density was $15 \mathrm{~mA} / \mathrm{cm}^{2}$. Then the samples were washed in acetone to remove residual sulfur and finally dried in nitrogen and annealed in air at $400^{\circ} \mathrm{C}$ for 20-30 minutes.

The structural analysis of the grown NW was carried out on a Rigaku X-ray diffractometer of the Miniflex 500 model with $\mathrm{CuK} \alpha$ radiation $(\lambda=1.5418 \AA)$. Note that Energy Dispersion X-ray analysis (EDAX) was also carried out through the use of Bruker Nano GmbH, b Berlin, Germany, whereas Raman and Photoluminescence spectra - by means of confocal laser spectroscopy (model "Tokyo Instruments"). XRD patterns have been recorded over the range of $20^{\circ}-75^{\circ}$ at the scan rate of $2 \% \mathrm{~min}$.

\section{RESULTS AND DISCUSSION}

The resulting CdSNW electrodeposited in $\mathrm{Al}_{2} \mathrm{O}_{3}$ pores were optically transparent over a wide spectral range. The diameter of the grown CdS NW ranged between 20-40 nm depending on the duration of deposition process. The EDAX spectrum (Fig.1) of CdS NW exhibits peaks of $\mathrm{Cd}, \mathrm{S}, \mathrm{O}, \mathrm{Na}, \mathrm{K}, \mathrm{Si}$, and In series with $\mathrm{Cd}: \mathrm{S}=36,73: 35,60$ indicating the films to be $\mathrm{Cd}$ stoichiometric, perhaps, due to the greater reactivity of $\mathrm{Cd}$ ions than $\mathrm{S}$ ions.

Comparing the intensities of the $\mathrm{Cd}$ (36.73\% at) and S (35.6\% at) peaks, it may be inferred that the composition of CdS is close to stoichiometry. The presence of In and oxygen with ITO layer is observed.
In addition to $\mathrm{Cd}$ and $\mathrm{S}$ peaks, $\mathrm{Si}$ and $\mathrm{O}$ signals are also observed. The Si signal is from glass substrate. The presence of oxygen is, perhaps, associated, first of all, with substrate, as well as oxides of $\mathrm{In}_{2} \mathrm{O}_{3}$ and $\mathrm{SnO}_{2}$, constituting ITO. Besides, as shown below, the X-ray diffraction of the structure shows the presence of an impurity phase of $\mathrm{CdO}$ which follows from the CdS oxidation in air. Therefore, the presence of oxygen in the system is a result of the same factor.

X-ray diffraction pattern of the $\mathrm{Al}_{2} \mathrm{O}_{3} / \mathrm{ITO} /$ glass and $\mathrm{CdS} \mathrm{NW}$ grown in $\mathrm{Al}_{2} \mathrm{O}_{3} / \mathrm{ITO} /$ glass substrates is shown in Fig.2a, and $2 \mathrm{~b}$ respectively. It contains more than 18 peaks of varying intensity and blur. In Fig.2ITO 
the peak at $2 \theta=22,020$ is solely available while the broad peak resulting from the $\mathrm{Al}_{2} \mathrm{O}_{3}$ indicated that AAO is amorphous.
The observed values of inter planar spacing (d), miller indices (hkl) as well as basic and impurity phases of CdS NW are presented in the Table.

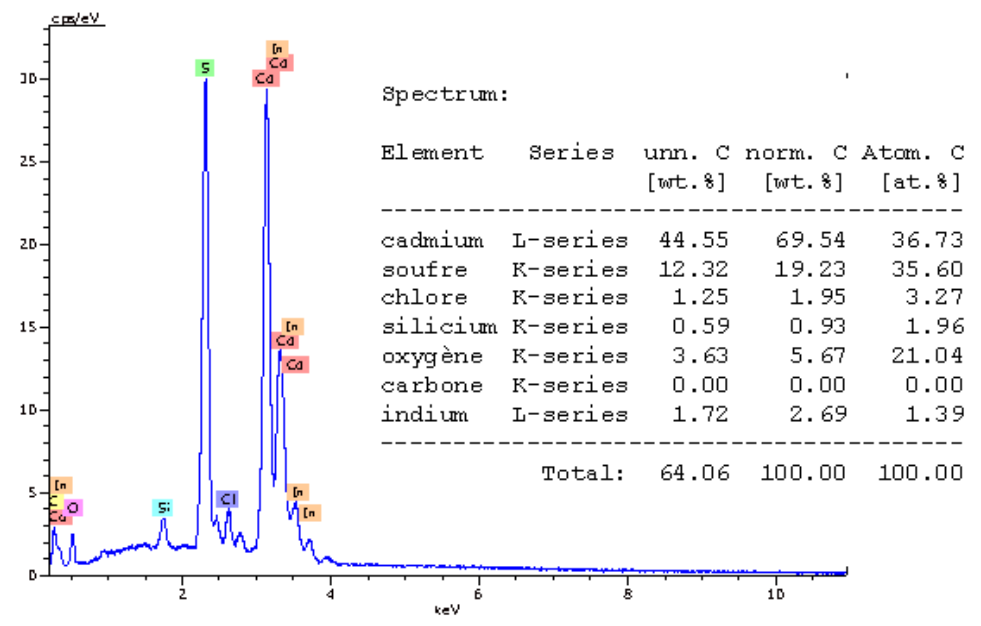

Fig.1. EDAX spectrum (a) and elemental composition of CdS

Table . The observed values of lattice spacing (d), miller indices (hkl) and basic phase of CdS.

\begin{tabular}{|c|c|c|c|c|c|}
\hline peaks No & $\mathbf{2 \theta}$ & $\mathbf{d}, \mathbf{A}$ & $\begin{array}{c}\text { Muller Index } \\
\mathbf{( h k l )}\end{array}$ & $\begin{array}{c}\text { Basic phase of } \\
\text { CdS }\end{array}$ & $\begin{array}{c}\text { Impurity } \\
\text { phases }\end{array}$ \\
\hline 1 & 22.020 & 4.12212 & - & - & $\left(\right.$ ITO $\left.^{*}\right)$ \\
\hline 2 & 24.874 & 3.57668 & 100 & Hexagonal & - \\
\hline 3 & 26.527 & 3.3660 & 002 or & $\begin{array}{c}\text { Hexagonal or } \\
\text { cubic }(* *)\end{array}$ & $\mathbf{( * *}^{* *}$ \\
\hline 4 & 28.247 & 3.1568 & 101 & Hexagonal & - \\
\hline 5 & 31.458 & 2.916 & - & - & $\left(\right.$ ITO $\left.^{*}\right)$ \\
\hline 6 & 34.145 & 2.704 & - & - & $\left(\right.$ ITO $\left.^{*}\right)$ \\
\hline 7 & 36.682 & 2.44793 & 102 & Hexagonal & - \\
\hline 8 & 38.657 & 2.2704 & - & - & CdO \\
\hline 9 & 43.805 & 2.06499 & 110 & Hexagonal & - \\
\hline 10 & 43.889 & 2.06121 & 220 & & Cubic \\
\hline 11 & 47.905 & 1.89741 & 103 & Hexagonal & - \\
\hline 12 & 51.028 & 1.78834 & 200 & Hexagonal & - \\
\hline 13 & 51.944 & 1.75894 & 112 & Hexagonal & - \\
\hline 14 & 51.98 & 1.75781 & 311 & & Cubic \\
\hline 15 & 52.943 & 1.7281 & 201 & Hexagonal & - \\
\hline 16 & 54.478 & 1.68297 & 222 & & Cubic \\
\hline
\end{tabular}




\begin{tabular}{|l|l|l|l|l|l|}
\hline 17 & 54.626 & 1.67875 & 004 & Hexagonal & - \\
\hline 18 & 58.422 & 1.5784 & 202 & Hexagonal & $\ldots$ \\
\hline
\end{tabular}

Notes: (*)Peaks number 1, 5 and 6 are related to ITO.

(**)It is known that high quality as-deposited CdS NW have just one preferred orientation corresponding to either cubic (111) or hexagonal (002), but it is difficult to distinguish these two phases based on the XRD peak position [10].

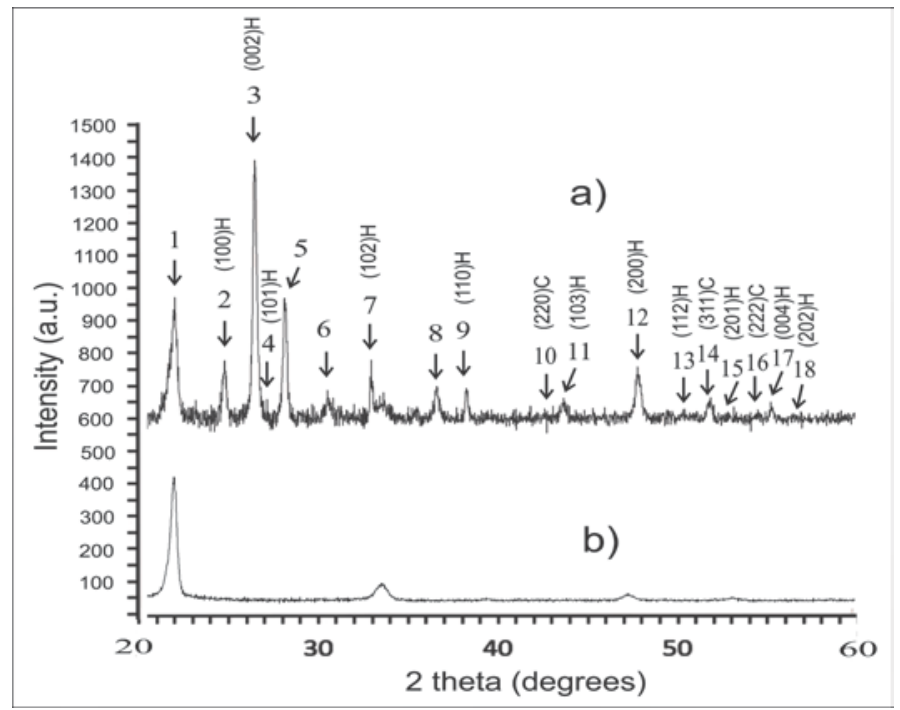

Fig. 2. XRD pattern of $\mathrm{CdS} / \mathrm{Al}_{2} \mathrm{O}_{3} / \mathrm{ITO} / \mathrm{Glass}$ (a) and $\mathrm{Al}_{2} \mathrm{O}_{3} / \mathrm{ITO} / \mathrm{Glass}$ (b) system.

As shown in Table, the observed diffraction peaks are formed mainly by the CdS planes of the hexagonal modification (belonging to the space group P-63mc (186)) by responses from the ITO layer (peaks Nos.1,5 and 6), planes (220), (311) and (222) CdS of the cubic modification (space group F-43m (216)), as well as response from the $\mathrm{CdO}$ phase (peak No. 8). Taking into account the relatively low intensities of the response from the cubic phase and $\mathrm{CdO}$, we regard it as the impurity phase, and the hexagonal phase as the main phase. As has been noted in [11], the blurriness of some peaks with a width of some $1^{\circ}$ reveals the nanocrystalline structure of the material. The narrowest and most intense reflex (peak No.3) and, correspondingly, the structure with greater crystallinity, is observed for the (002) plane of the hexagonal modification of CdS. Therefore, crystal growth occurs mainly in the plane corresponding to this reflex, which is very typical for thin-film CdS [10]. The presence of an impurity phase of $\mathrm{CdO}$ is apparently due to the oxidation of CdS in air. The average size $\mathrm{d}(\AA)$ of CdS crystallites was deduced to be $35 \mathrm{~nm}$ from the peak No. 3 ofthe experimental XRD pattern using the Debye-Scherer formula $\mathrm{d}$ $=\mathrm{k} \lambda / \beta \cos \theta$, where $\theta\left(13.25^{\circ}\right)-$ is the maximum scattering Bragg angle, $\beta\left(0.23^{\circ}\right)$ - is the full width half maxima (FWHM) of the diffraction peak, $k \approx 0.89$ is Scherer factor for spherical nanoparticles, $\lambda$ - implies the wavelength of the X-ray used. 


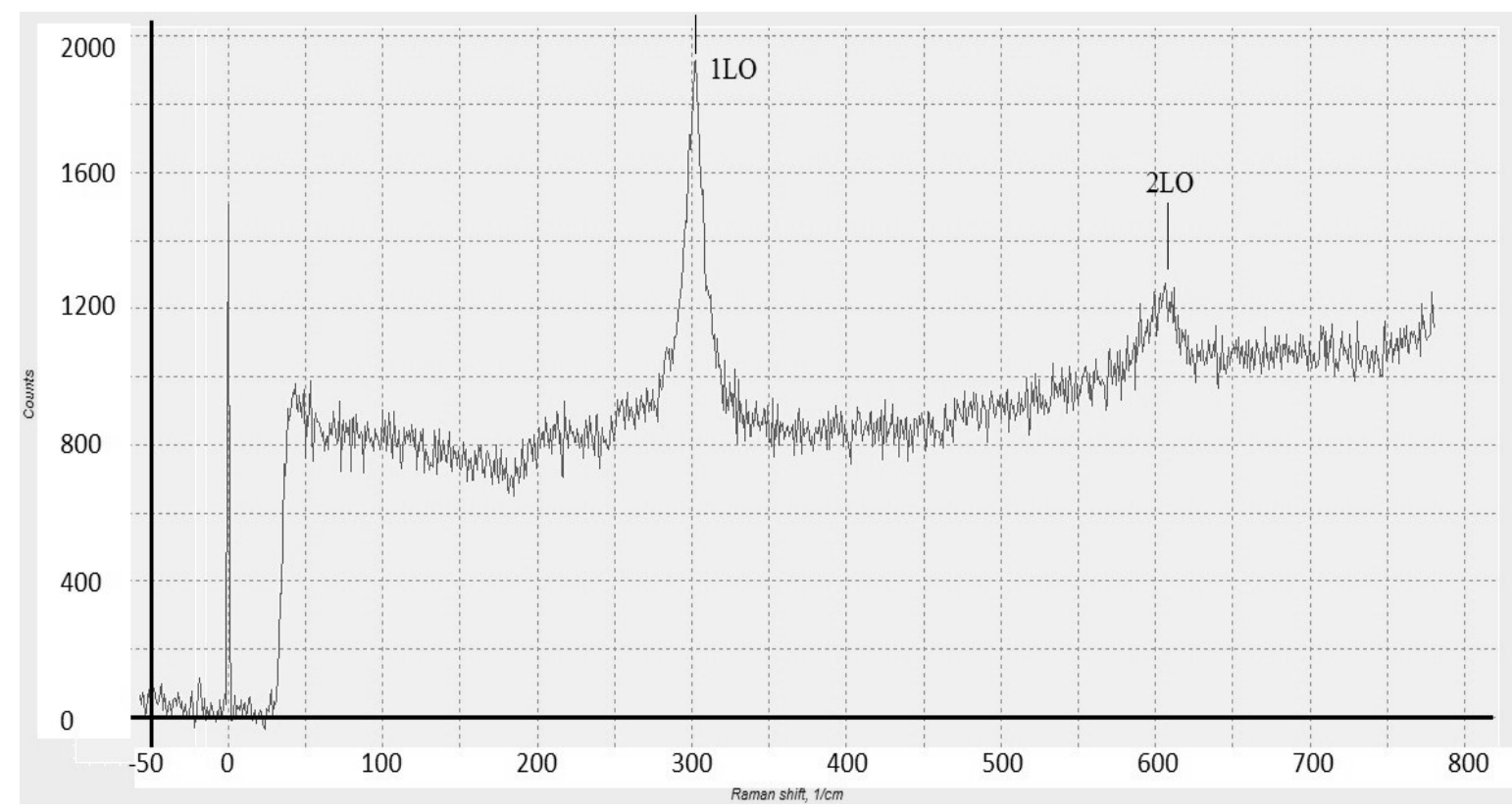

Fig.3. The Raman spectrum of CdS NW/ITO/glass system.

Figure 3 shows the spectrum of Raman scattering of CdS NW taken in the backscattering configuration and analyzed by using the model of "Tokyo Instruments" spectrometer at room temperature. As an excitation source we used the $532 \mathrm{~nm}$ line of an $\mathrm{Ar}$ - iron laser. The dominant structure in these spectra is longitudinal mode at $305 \mathrm{~cm}^{-1}$ and its first overtone at $611 \mathrm{~cm}^{-1}$, which is consistent with the fact that the one of the striking features of the Raman spectra CdS is the remarkable overtones series of the longitudinal optical phonons [12].The peak corresponding to the optical background mode (1LO) of the first order is inherent in the hexagonal (wurtzite) modification of CdS, as well as the peak at 605 $\mathrm{cm}^{-1}$ corresponding to the optical background mode CdS (2LO) of the second order and corresponding to the cubic (sphalerite) modification of CdS. The presence of these peaks is confirmed by the data obtained on the basis of the difractogram.

The room-temperature photoluminescence (PL) measurement results of the CdSNW in their AAO matrix are shown in Figure 4. The excited wavelength made up $532 \mathrm{~nm}$ (which was apparently weaker than the edge of CdS' own absorption), and no filter was used. Although some short wavelengths had been used as excitation light in PL measurements, only one emission band with a maximum at about $760 \mathrm{~nm}$ could be observed and its intensity was relatively weak. 


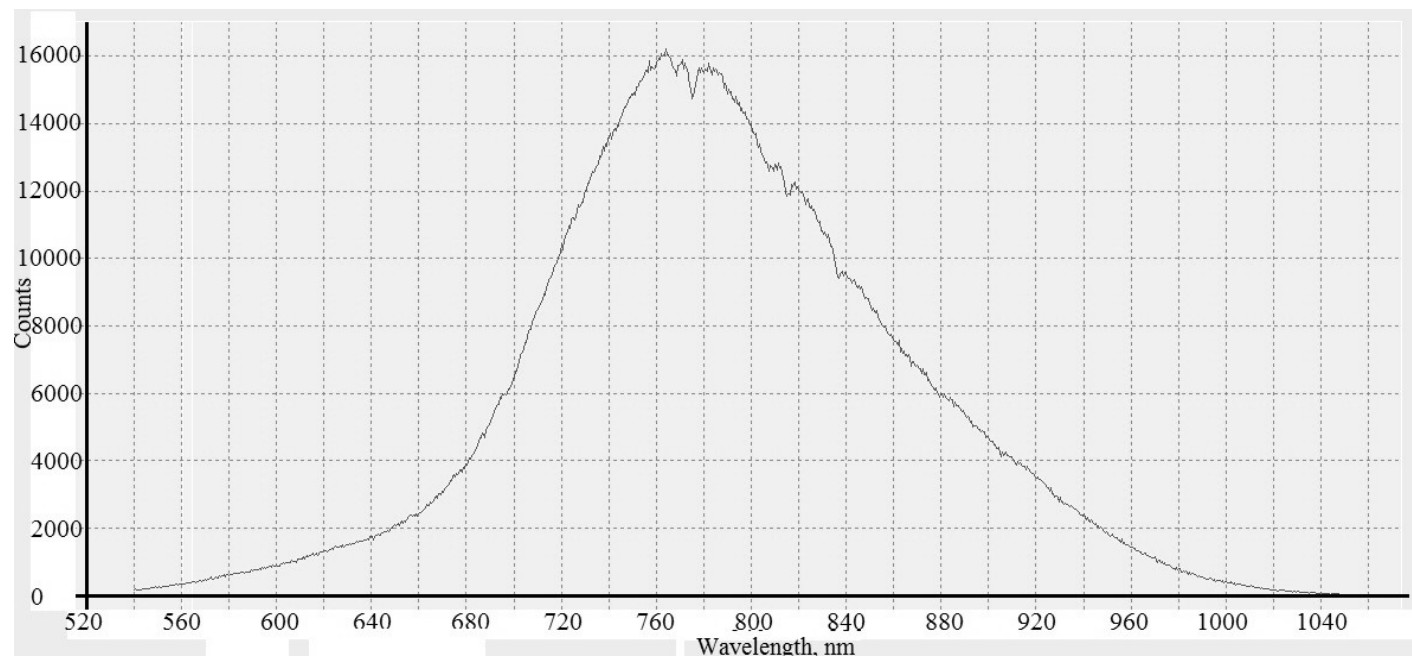

Fig.4. The PL spectra of CdSNW

The luminescence mechanisms of CdS have been studied over a few decades [13,14]. Usually, two emissions are observed from semiconductor nano particles excitonic and trapped luminescence $[15,16]$. The first one is observed at 380- $475 \mathrm{~nm}$ around the band edge and is attributed to higher-level transition while the other at $690 \mathrm{~nm}$ is due to trap or surface states. It is believed that the trap emission is mainly due to the excess of sulfur at the interface which is well-known to quench radiative band gap recombination, and not to the low crystalline of the particles.

In addition, the diameters of our synthesized CdSNW $(35 \mathrm{~nm})$ are significantly larger than the exciton Bohr diameter in CdS. Therefore, the luminescence from the synthesized CdSNW observed by us at $750 \mathrm{~nm}$ is the trapped emission.

\section{CONCLUSION}

The structural-morphological properties of CdS thin films electrodeposited on ITO glass/AAO substrate from non-aqueous solution are analyzed. XRD patterns indicated that the structure of CdS thin film is cristallinity and hexagonal, the Raman scattering, the elemental composition and morphology SEM micrographs as well as the photoluminescence (PL) spectra indicates that the selected composition of anhydrous electrolyte $\left(0.2 \mathrm{M} \mathrm{CdCl}, 0.02 \mathrm{M} \mathrm{S}_{8}\right.$, $0.1 \mathrm{M} \mathrm{NH} \mathrm{N}_{4} \mathrm{Cl}$ ) dissolved in ethylene glycol and the electrodeposition film mode, allow to form layers of nano-crystalline CdS thin films with stoichiometric composition and predominately hexagonal characteristics suitable for the use as a window layer in $\mathrm{CdS} / \mathrm{Cu}_{2} \mathrm{~S}$, CdS/CdTe, $\mathrm{CdS} /$ $\mathrm{CdS} / \mathrm{CuInGaSe}$, etc. hetero junction solar cells.

This work was carried out with the financial support of the Foundation for the Development of Science under the President of the Republic of Azerbaijan, grant No. EIF-2014-9 (24) KETL14/04/04-M-13.

\section{REFERENCES}

1. Piao Liu. Heterojunctions and Schottky diodes on semiconductor nanowires for solar cell applications, $\mathrm{PhD}$ Thesysis, University of Kentucky, 2010, 153 p. 
2. Ryo Asaba, Kazuki Wakita, Atsushi Kitano, Yong Gu Shim, Nazim Mamedov, Ayaz Bayramov, Emil Huseynov and Ilham Hasanov. Structural and optical properties of CdS:O thin films. Phys. Status Solidi. 2013, no.10, pp. 1-4.

3. Abdolahzadeh A. Ziabari, Ghodsi F.E. Growth, characterization and study into sol-gel derived CdS nano crystalline thin films incorporated in polyethyleneglycol: Effects of post-heat treatment.Solar Energy Materials and Solar Cells. 2012, vol. 105, pp. 249262.

4. Lisco F., Kaminski P.M., Abbas A. et al. Structural properties of CdS deposited by chemical bath deposition and pulsed direct current magnetron sputtering. Thin Solid Films. 2015, vol. 582, pp. 323-327.

5. Fangyang L., Yanging L., Jun L. Characterization of chemical bath deposited CdS thin films at different deposition temperature. Journal of alloys and compounds.2010, vol. 493, pp. 305-308.

6. Mahdi M.A., Kasem S.J., Hassen J.J.et al. Structural and optical properties of chemical deposition CdS thin films. Int.J.Nanoelectronics and materials. 2009, no. 2, pp.163-172.

7. Mahmoud El-Rouby, Aliyev A.Sh., Hasanov Ch.A., Mamedov M.N. Electrodeposition of cadmium sulphide. Kimya Problemleri - Chemical Problems. 2012, no.2, pp. 194-206. (In Azerbaijan).

8. Eminov Sh.O., Tagiyev D.B., Aliyev A.Sh., Jalilova Kh.D. et.al. Nanostructured hybrid of photovoltaic solar cell and supercapacitor. Proceeding of $31^{\text {st }}$ European Photovoltaic Solar Energy Conference and Exhibition, Hamburg, Germany, 1418 September, 2015, pp.1235-1237.
9. Eminov Sh.O., Tagiyev D.B., Aliyev A.Sh.et al. Photo and electrical peculiarities of the nanostructured glass/ITO/ AAO and glass-ITO/CdS. $J$. Mater Sci: Mater Electron., $\quad 2016$, vol. 27, pp. 9853-9860.

10. Kadirgan F., Mao D., Song W. et al. Properties of electrodeposited cadmium sulfide films for photovoltaic devices with comparison to CdS films prepared by other method. Turk J.Chem.,Tubitak. 2000, vol. 24, pp. 21-23.

11. Routkevitch D., Haslett T.L., Ryan L. et al. Electrochemical fabrication of CdS nanowire arreys in porous anodic aluminum oxide templates. Journ. Chem. Phys. 1996, vol.100, pp. 1403714047.

12. Chuu D.S., Dai C.M., Hsieh W.F. and Tsai C.T. Raman investigation of the surface modes of the crystallites in CdS thin films grown by pulsed laser and thermal evaporation. Journ.Appl.Phys. 1991, vol. 69(12), pp. 8402-8404.

13. Chuan Hu, Xianghua Zeng, Jieya Cui, Haitao Chen and Junfeng Lu. Size effects of Raman and Photoluminescence spectra of CdS nano belts. The Journ. of Phys. Chem. C. 2013, vol. 117 (40), pp. 20998-21005.

14. Srinivasa B. Rao, Rajesh B. Kumar, Rajagopal V. Reddy et al. Preparation and characterization of CdS nanoparticles by chemical coprecipitation technique. Chalcogenide Letters. 2011, vol. 8, no. 3, pp. 127-185.

15. Abdi A., Titova L.V., Smith L.M. and Jackson H.E. Resonant Raman scattering from CdS nanowires. Appl. Phys. Lett. 2006, vol. 89-89, 043118.

16. Shripriya Poduri, Mitra Dutta and Michael Stroscio, Characterization of CdS nanowires self-assembled in a nanoporous alumina template. Journ. of Electronics materials. 2014, vol. 43, no. 11, pp. 3979-3983. 


\title{
ELEKTROKIMYӘVİ ÜSULLA ÇÖKDÜRÜLMÜŞ CAS NANOTELLӘRİNIN BӘZI XÜSUSIYYOTLORI
}

\author{
A.Ş. Oliyev ${ }^{1}$, V.A. Mocidzado ${ }^{1}$, N.Ş. Soltanova ${ }^{1}$, D.B. Tağıyev ${ }^{1}$, V.N. Fateyev ${ }^{2}$ \\ ${ }^{1}$ AMEA akad. M. Nă̆ıyev adına Kataliz və Qeyri-üzvi Kimya İnstitutu \\ AZ 1143 Bakl, H. Cavid pros.113, e-mail: chim.prob.tur@rambler.ru \\ ${ }^{2}$ Rusiya Milli Tadqiqat Markazi "Kurçatov İnstitutu", \\ Rusiya 123182, Moskva, akad. Kurçatovmeydanı,e-mail: nrcki@nrcki.ru
}

Elektrokimyəvi üsulla tərkibində kadmium-xlorid (0.2 $\mathrm{M} \mathrm{CdCl}_{2}$ ), kükürd (0.02 $\mathrm{M} \mathrm{S}_{8}$ ), ammonium xlorid (0.1 $\mathrm{M} \mathrm{NH}_{4} \mathrm{Cl}$ ) saxlayan, $T=120-130^{\circ} \mathrm{C}$-də etilenqlikolda hall olan susuz mahluldan, 90-100 ${ }^{\circ} \mathrm{C}-d \partial$ məsaməli alüminium-oksid (anodda oksidlaşmiş alüminium) üzərinə çökdürülmüs 30-40 $\mathrm{nm}$ diametrə malik kadmium sulfid (CdS) nanotellarinin kristaloqrafik strukturu va element tarkibi öyranilmişdir. Çökdürülan CdS nanotellari enerji dispersiya X-ray spektrometriyası (EDX), rentgen diffraktometriyası $(X R D)$, Raman sapilma va fotolüminesens (PL) spektrlari ila xarakteriza edilmişdir. Müəyyən edilmişdir ki, seçilan elektrolitin tərkibi və elektroçökmə şərtlari günəş çeviricilorində istifadə üçün yararlı olan, stexiometrik tərkibə uyğun altıbucaqlı modifikasiyaya malik CdS nanotellarinin formalaşmasına imkan verir.

Açar sözlər: nanotellər, kadmium-sulfid, elektrokimyəvi çökmə, susuz məhlul, etilen qlikol, XRD, EDX, kombinasion sapalanma, fotolüminessensiya spektrlari.

\section{НЕКОТОРЫЕ ОСОБЕННОСТИ ЭЛЕКТРОХИМИЧЕСКИ ОСАЖДЕННЫХ НАНОПРОВОДОВ CdS}

\author{
А.Ш. Алиев ${ }^{1}$, В.А. Маджидзаде ${ }^{1}$, Н.Ш. Солтанова ${ }^{1}$, Д.Б. Тагиев ${ }^{1}$, В.Н.Фатеев \\ ${ }^{1}$ Институт Катализа и Неорганической Химии Национальной АН Азербайджана \\ AZ 1143, Баку, nр. Г.Джавида, 113, e-mail: chim.prob.tur@rambler.ru \\ ${ }^{2}$ Российский национальный исследовательский иентр «Курчатовский Институт» \\ 123182 Россия, Москва, пл. Академика Курчатова, д. 1; e-mail: nrcki@nrcki.ru
}

Изучены кристаллографическая структура и элементный состав нанопроводов CdS $c$ диаметром в диапазоне 30-40 нм, изготовленных путем электроосаждения при 90-100 С в поры анодного оксида алюминия из неводного раствора, содержащего хлорид кадмия (0.2 $\left.\mathrm{M} \mathrm{CdCl}_{2}\right)$, серу $\left(0.02 \mathrm{M} \mathrm{S}_{8}\right)$ и хлорид аммония $\left(0.1 \mathrm{M} \mathrm{NH}_{4} \mathrm{Cl}\right)$, растворенных в этиленгликоле при $\mathrm{T}=120$ $130^{\circ} \mathrm{C}$. Осажденные нанопровода CdS исследованы методами энергодисперсионной рентгеновской спектроскопии (EDX), рентгеновской дифрактометрии (XRD), комбинационного рассеяния и фотолюминесиенции (PL). Было обнаружено, что выбранная композиция электролита и условия электроосаждения позволяют сформировать CdS нанопровода $c$ преимущественно гексагональной модификацией, а стехиометрический состав подходит для использования в солнечных преобразователях энергии.

Ключевые слова: нанопроволока, сульфид кадмия, электрохимическое осаждение, неводный раствор, этиленгликоль, XRD, EDX, комбинационное рассеяние, спектры фотолюминесценции. 